\title{
Company Value Development by Supply Chain Management
}

\author{
Gerhard LECHNER \\ University of Sopron \\ Hungary \\ Alexandre Lamfalussy Faculty of Economics \\ Doctoral School \\ H-9400 Sopron, Erzsébet Street 9
}

\begin{abstract}
Increasing the value of the company is one of the main tasks of the management in order to survive in the market in the long term. Due in part to the very high proportion of value creation at suppliers outside of the company, especially in the case of manufacturing companies, the development of the company is strongly influenced by them. Suppliers are increasingly involved in processes of their customers or even take over processes by themselves. As a result, the management of supplier relationships through purchasing is important. The type of the cooperation with the suppliers is in a sustainable process of change, in particular due to Industry 4.0. Nevertheless, it is still crucial to generate Value Added through supplier contributions. For these reasons, quantifiable contributions by suppliers to increase Company Value are examined, taking into account the general conditions and opposing effects. One key finding from the study is that purchasing has the highest impact on increasing Company Value from product and production cost improvements with suppliers. Therefore, for a successful, sustainable supplier relationship an excellent delivery and quality performance is of high importance, which in turn represents the basis for future Value Contributions. The influences from Industry 4.0 contribute in particular to the improvement of process costs and information flows. It is also expected overall that the intensity of cooperation with suppliers will continue to increase over the next five years.
\end{abstract}

Keywords: Industry 4.0, Company Value, Supply Chain Management, Value Added, Value Contribution

\section{Introduction}

The importance of Supply Chain Management has increased significantly in recent decades, as companies have increasingly focused on their core competences and shifted value creation to suppliers in order to generate higher Value Contributions and to be able to shift risks in parallel (Hofbauer et al., 2015, p.3). According to information from the Federal Statistical Office in Germany, the share of material consumption including merchandise and wage labor in the gross production value in manufacturing is on average $58.0 \%$ and in mechanical engineering 53.9\% (Federal Statistical Office, 2018, p. $278 \&$ p. 301). The cost of materials thus represents the largest cost block in the manufacturing industry, from which the necessity of an efficient and systematic Supply Chain Management derives.

\section{Supply Chain Management}

„Supply Chain Management (SCM) views the supply chain as a single entity rather than relegating fragmented responsibilities for various segments in the supply chain to functional areas such as purchasing, manufacturing, distribution, and sales...Supply Chain Management requires a new approach to systems: Integration, not simply interface, is the key." (Autry \& Moon, 2016, p. 4; Oliver \& Webber, 1982, pp. 42-47). Other Supply Chain Management definitions from various authors are e. g. to be found at Freiwald (2005, p. 9), Monczka et al. (2015, p. 13) and Mau (2003, p. 22).

The contribution from procurement activities to the company's success has become increasingly important in recent years. In addition to subcontraction and outsourcing of production processes for reasons of optimizing or selling production or production facilities with partly subsequent closure of the divisions, this also includes the procurement of components and merchandise that goes into the company's own products (Schäffer \& Weber, 2005, p. 1). Logistics as part of Supply Chain Management includes all activities with a holistic focus in the areas of planning, control and control related to the flow of information, materials and value. The right goods should be available at the right time, in the right place, in the appropriate quantity and quality at the best possible cost (Arndt, 2018, pp. 35f.). However, Supply Chain Management is much more comprehensive because it tracks the cross-company coordination and optimization of processes and flows throughout the value chain. This means that the suppliers' suppliers must also be in the focus in order ultimately to be able to satisfy the needs of the customers in an excellent way (Arndt, 2018, p. 44). 
This also changes the perspective in the competitive environment, which moves from company competition to supply chain competition (Arndt, 2018, p. 45). Companies have the choice to produce as much as possible by themselves or to focus on core competencies and to buy non-strategic components from outside. With this concept better solutions - in the benchmark with in-house production - can be mapped. Fixed costs can also be more easily variabilized (Arndt, 2018, pp. 155f.). A holistic Supply Chain Management also includes a company strategy. This is comprehensively supported by information technology and enables the optimization of the supply chain in addition to the permanent analysis of the processes, in particular at the interfaces. Such concepts are indispensable in the automotive industry; other industries have now followed suit. Ultimately, the main goal of Supply Chain Management is to be able to give customers reliable delivery date forecasts, supported by planning dependability, flexibility and transparent costs (Baumgarten, 2004, p. 52).

Concepts such as the Vendor Managed Inventory (Appelfeller \& Buchholz, 2011, p. 248; Arndt, 2018, pp. 163f.) underline this approach and also build on a close cooperation between customer and supplier in order to - possibly supported by information technology - realize optimization potentials in the supply chain together. In addition, the choice of the procurement model (Appelfeller \& Buchholz, 2011, pp. 285-287) can highly influence the relationship of a customer to one's own company. Companies need to think about how they want to do the procurement. According to Arnold (2000, pp. 42-44; see also Fandel et al., 2009, p. 56) directional decisions are therefore necessary, whether e. g. local or global, centralized or decentralized, etc. should be procured. The differentiation of the sourcing strategies can be taken from each characteristic in the following Figure 01.

\begin{tabular}{|c|c|c|c|c|}
\hline Supplier & Sole & Single & Dual & Multiple \\
\hline Procurement Object & Unit & \multicolumn{3}{|c|}{\begin{tabular}{l|l} 
Modular & System
\end{tabular}} \\
\hline Procurement Subject & \multicolumn{4}{|c|}{ Collective } \\
\hline Procurement Area & Local & \multicolumn{3}{|c|}{ Global } \\
\hline
\end{tabular}

Fig. 01: Systematization of Sourcing Concepts (Source: cf. Fandel, 2009, p. 56; cf. Schulte, 2004)

The utilization of sourcing strategies is not in all cases a completely free decision of the company, e. g. if sole sourcing cannot be avoided. Nevertheless, the goal is always to combine the respective sourcing concepts with one another (Fandel, 2009, pp. 62f; Arnold, 1997, pp. 93ff.), that the highest Value Added can be achieved with holistic consideration of all opportunities and risks.

\section{Methodolody and Research}

The investigation was conducted between August and November 2017. A total of 628 companies were contacted in writing via a standardized and structured questionnaire. The contact was made by email, LinkedIn or personal delivery. 68 questionnaires were answered, which corresponds to a response rate of $10.8 \%$.

In order to receive qualified feedback, explicitly experienced purchasing representatives, some of them from middle or higher management, were addressed. In addition, it must be clear that the company belongs to the manufacturing sector. This industry focus has been chosen because the requirements of different industries sometimes differ greatly. The classification or branch is carried out according to the definition of the main industrial groups of the European Community (Official Journal of the European Communities, 2007, pp. 4ff.).

Furthermore, due to the query of the sales figures or the purchasing volumes, a different behavior between small and medium-sized enterprises (SMEs) and groups may be derived. The definition of SMEs is based on the Recommendation of the European Union (Official Journal of the European Union, 2003, p. L 124/39), which was also based on the Institute for SME Research Bonn in terms of turnover; the further gradations are determined on the basis of personal experience.

The purchasing volume is based on an average material quota of $50 \%$ and is classified analogously to sales. However, it is highly industry-dependent. The question of connecting purchasing within the organization allows conclusions to be drawn about the strategic importance and classification of the purchase. The purchasing agents participating in the survey have $80.9 \%$ of purchasing experience of more than ten years. $77.9 \%$ have completed a study. $82.4 \%$ of the participants in the respective companies stated that they held a managerial position. Of the participating companies, $72.1 \%$ were in the industrial goods sector $(66.2 \%$ of the companies were mechanical engineering alone) and $14.7 \%$ were in the intermediate goods sector. $94.1 \%$ of the companies generate a turnover of less than $€ 5.0$ billion and at $97.1 \%$ the purchasing volume is less than $€ 2.5$ billion. For $97.1 \%$ of the companies, purchasing is linked to the Executive Board, the Management Board or C-Level or represented therein. 
The purpose of this study is to gain insights into the type and intensity of cooperation with suppliers. For this, the main interfaces to the suppliers and the ways and possibilities of cooperation are explicitly questioned. The survey will also provide insights into the relationship between Value Contributions by suppliers and the development of the Company Value. Furthermore, the effects of Industry 4.0 on Supplier Management activities are considered.

\section{Results from the survey}

\subsection{Supplier integration and cooperation}

This section aims to identify the main channels of cooperation with suppliers. Furthermore, there are various ways and possibilities by which a relationship with the suppliers can be designed. Corresponding findings should be derived from the statements. The first results of the investigation relate to the cooperation of individual functions in the company with suppliers. The cooperation is therefore mainly by purchasing $(97.1 \%)$, by engineering department $(72.1 \%)$ and by procurement / material requirements planning (42.6\%). The areas of quality department $(27.9 \%)$, logistics (17.6\%) and management (14.7\%) play a subordinate role, and the importance of the areas of production, sales and the planning department are negligible in this context. See also Figure 02.

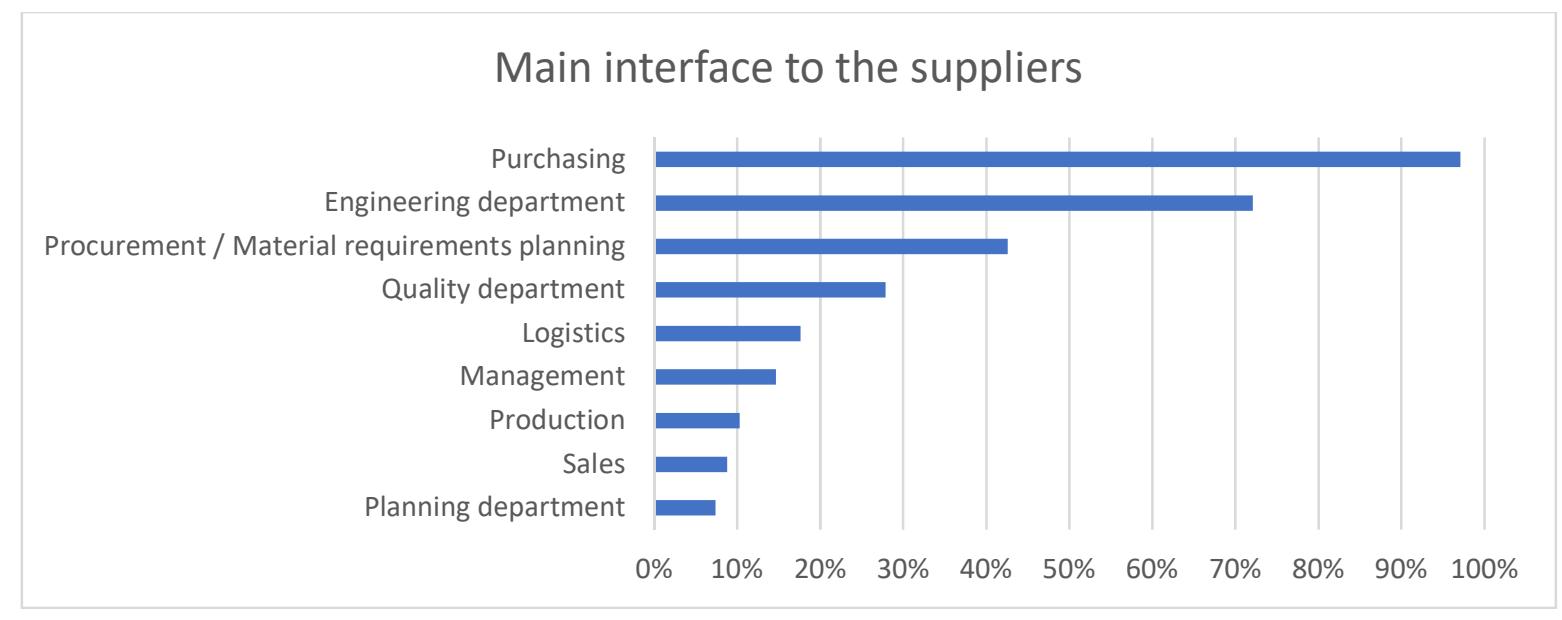

Fig. 02: Main Interface to the Suppliers

Likewise, the type of the cooperation with suppliers has been questioned, with particular reference to the execution of the cooperation. It is indicated that the traditional routines are still very important. The traditional exchange by e-mail, letter or telephone is rated as important at $97.1 \%$, followed by common discussions in the own company $(89.7 \%)$ and at supplier's location (86.8\%). Electronic order processing is also rated high at $60.3 \%$. In all other ways, the evaluation is given as about $30 \%$ or significantly lower. For example, the subject of auctions is last with approximately $10 \%$. The details are shown in Figure 03 below.

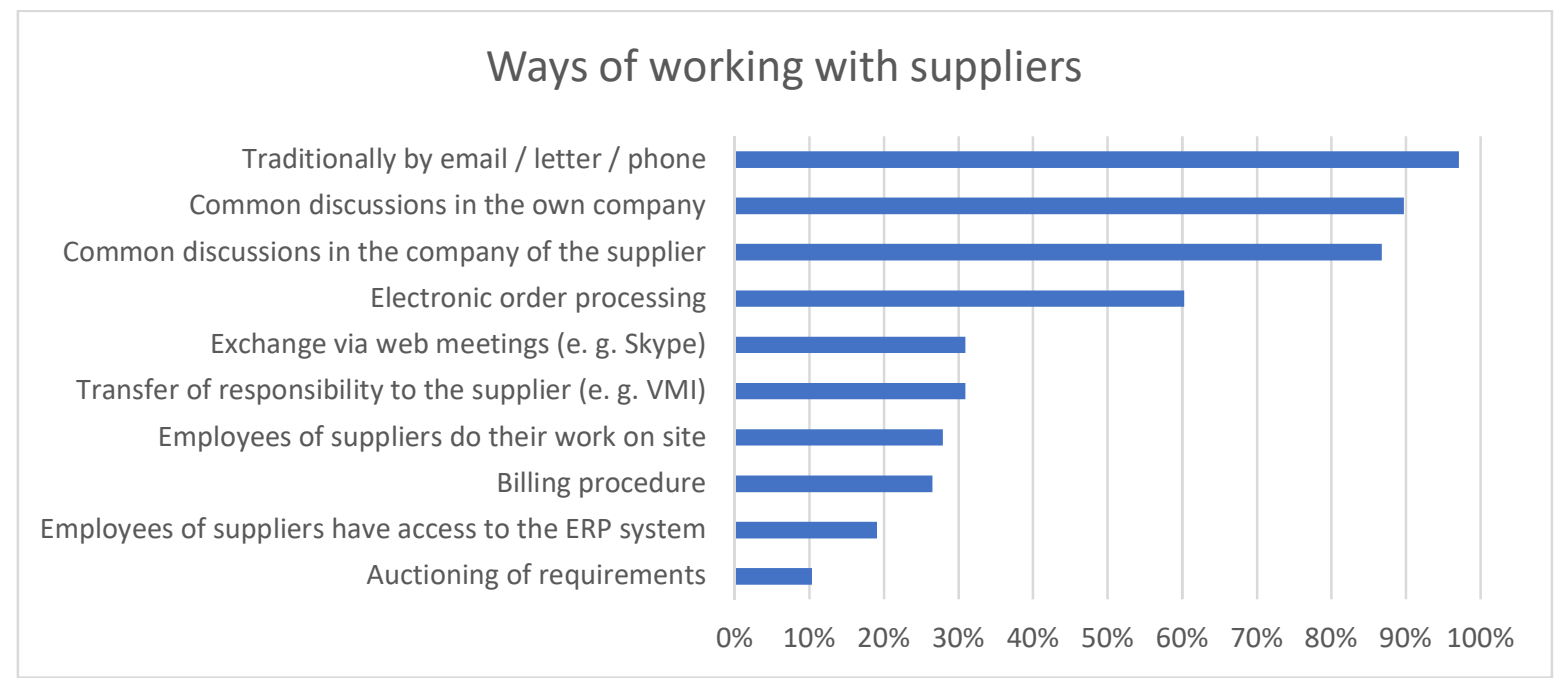

Fig. 03: Ways of working with Suppliers 
Of $73.5 \%$ of the company representatives surveyed, the development of cooperation with suppliers in five years compared to today is estimated to be even closer and more intensive. $25.0 \%$ expect a constant intensity; only $1.5 \%$ of company representatives, which means one company, expects a diminishing intensity of collaboration due to changed values.

\subsection{Increase of Company Value by suppliers}

This section deals with supplier contributions that are provided as Value Added to customer companies.

The highest impact is specified with $89.7 \%$ of reduced product and production costs, e. g. favorable purchase of components or services. With a considerable margin of $63.2 \%$ each, the improvement of product quality and the reduction of quality costs as well as product and process innovations by suppliers follow. The fourth place is taken by the shortening of product development times by early supplier integration, followed by increased flexibility in the own company by intelligent logistics concepts (59.1\%) and reducing the capital commitment costs by avoiding own inventory (54.4\%). Influences due to the assumption of risk by suppliers are of secondary importance. The details are shown in Figure 04 below.

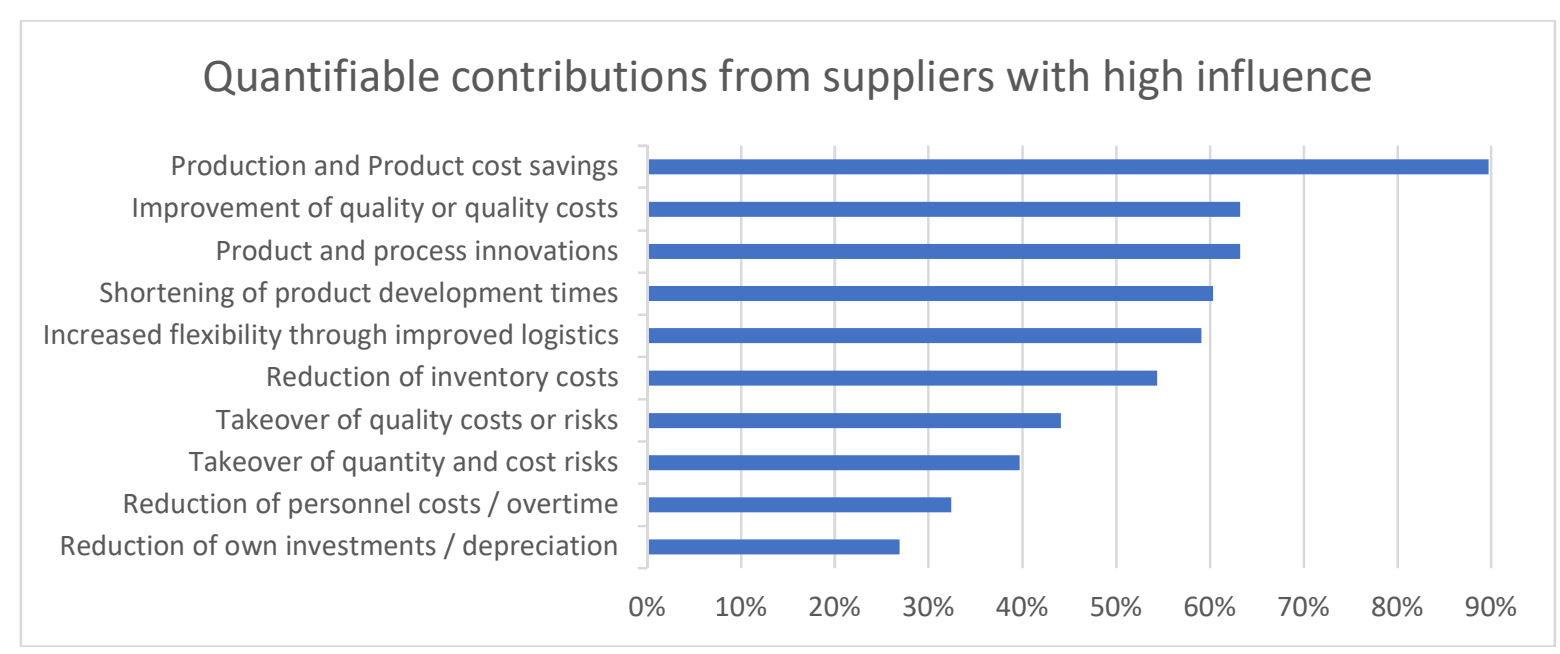

Fig. 04: Quantifiable Contributions from Suppliers with high influence

The framework conditions are examined as well on which Value Added depends by suppliers to increase Company Value. The reliability of the suppliers in terms of logistics and quality are mentioned first (93.9\%). The importance of this criterion is therefore rated higher than the existing know-how of suppliers $(88.1 \%)$. The complexity of the supplied components or assemblies is with $79.1 \%$ also rated as another important framework condition, followed by the supplier's cost structure $(68.7 \%)$ and the availability of the required products on the market $(67.2 \%)$. Furthermore, substitutability of product and supplier, as well as willingness or decisions to invest by suppliers, each with $53.7 \%$, are stated as important. The size of a supplier in terms of sales or employees is only of minor importance (19.4\%). See also Figure 05 .

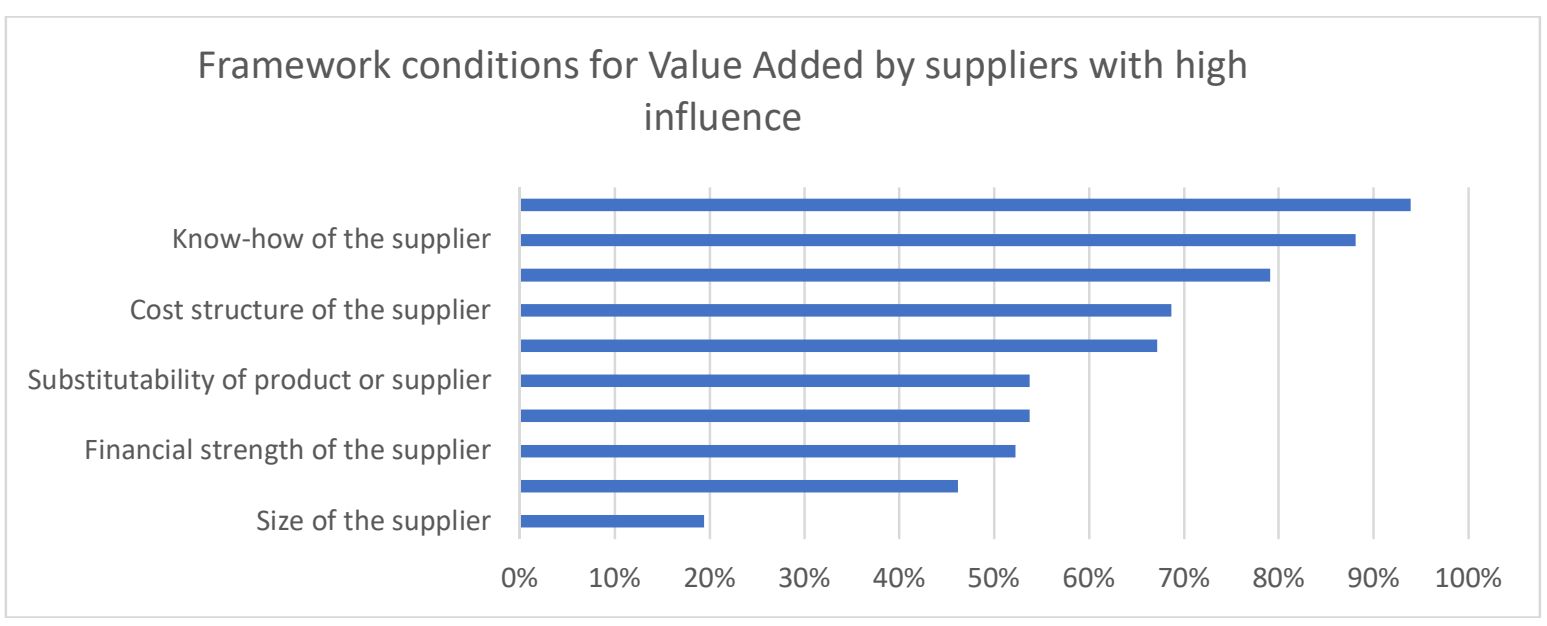

Fig. 05: Framework conditions for Value Added by Suppliers with high influence 
The following Figure 06 shows the quanitifiable opposing effects that lead to increased own costs in the context of supplier integration and in contrast to in-house production. The main opposing effects come from higher costs for development of a supplier relationship as well as from supplier support. These criteria are rated at $43.3 \%$ each. Likewise, with $35.8 \%$ each, higher travel or management costs as well as higher quality costs due to outsourcing are of opposite character. Effects from higher problem-solving costs (32.8\%), personnel expenses $(31.3 \%)$ and the increase in inventory risk or increased inventory costs conclude with $28.4 \%$ the feedback.

\section{Quantifiable opposing effects with high influence}

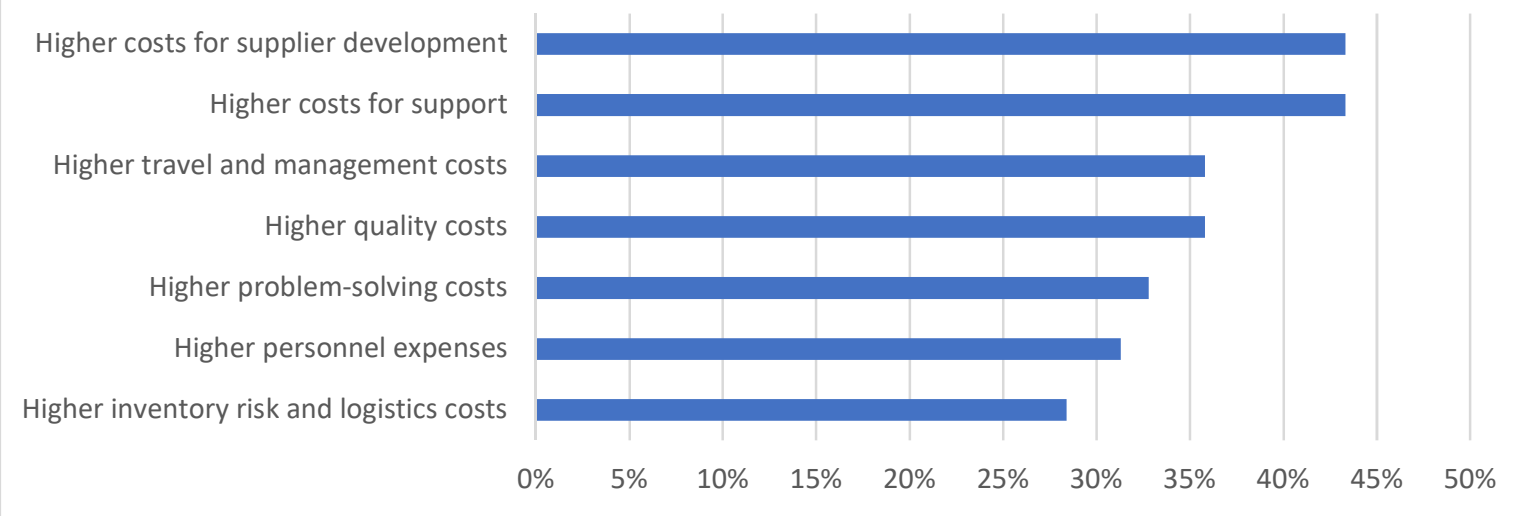

Fig. 06: Quantifiable opposing effects with high influence

Overall, it can be seen that the opposing influencing factors are rated below 50\%. From this it can be derived that the benefits of working with suppliers clearly exceed the costs.

\subsection{Optimization of purchasing activities through Industry 4.0}

The opportunities that arise for purchasing from the developments of Industry 4.0 are increasingly reflected in practical applications. This change is in full swing, obviously unstoppable and influences the work in purchasing in part very much. For this reason, the effects of the developments in Industry 4.0 related to the activities of purchasing will be questioned first. The main effects are seen in processes and information flows: optimization of ordering including reduction of inventory and inventory costs $(75.8 \%)$, speeding up the flow of information with the supplier $(74.2 \%)$ and in-house $(71.2 \%)$ as well as reduction of process costs in the own company $(71,2 \%)$. There are also high impacts in terms of reducing throughput times (68.2\%) and reducing leadtimes (59.1\%). Basically, a high impact on business processes is expected across the board, where the interaction between supplier and company is very close. Figure 07 below shows in detail the implications of Industry 4.0 developments that can help to optimize purchasing activities.

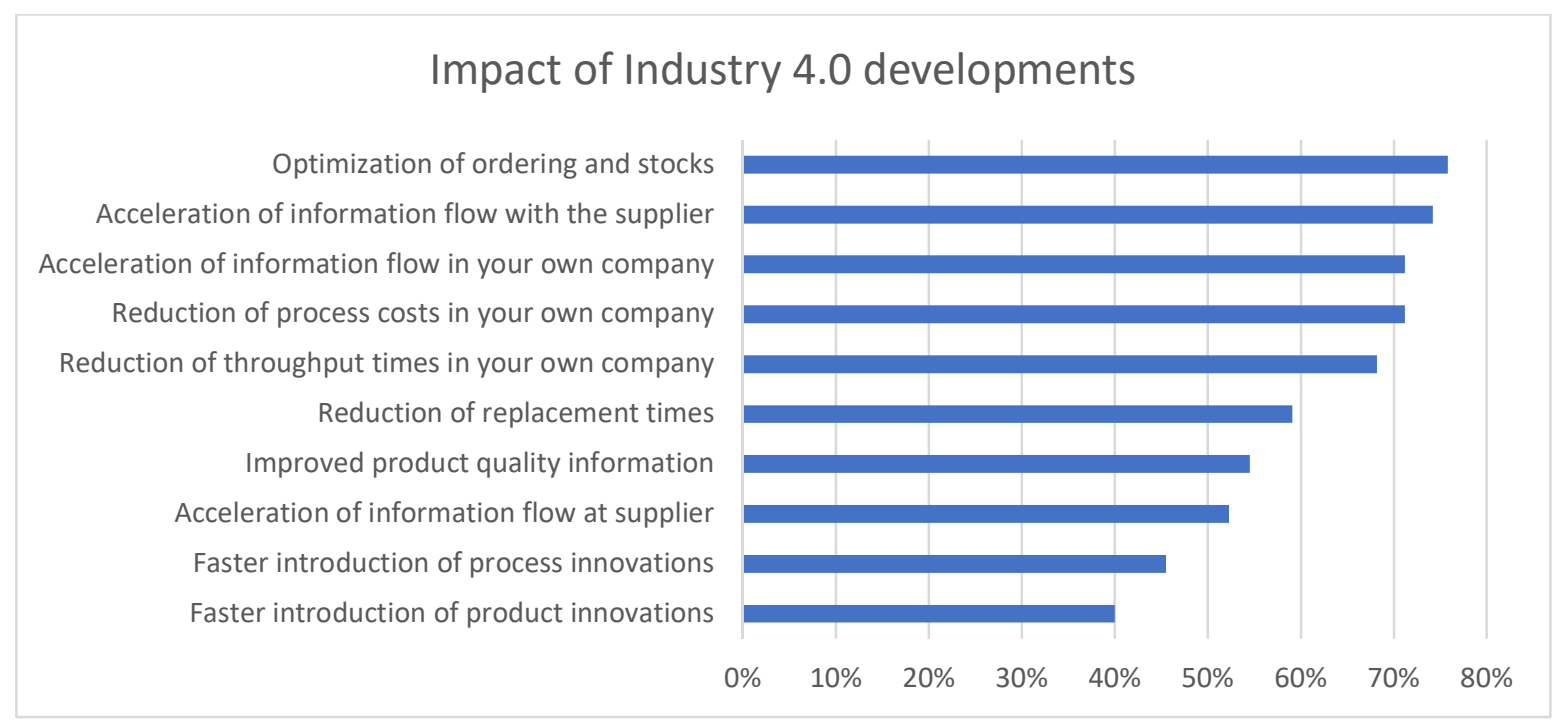

Fig. 07: Impact of Industry 4.0 developments 
Finally, Figure 08 shows the Value Contributions that can be realized in the company by the purchasing department based on the possibilities offered by Industry 4.0. As a result, Value Contributions from the reduction of transaction times and thus faster revenue generation $(59.1 \%)$ as well as indirect cost reductions through process optimization and process innovations / productivity increases (56.1\%) are the most important factors. Also important are inventory cost reductions (47.0\%) and the general increase in purchasing performance including the avoidance of cost increases $(40.9 \%)$. In the last place, direct cost reductions for components and assemblies are mentioned at only $27.7 \%$.

\section{Creation of Value Contributions from Industry 4.0}

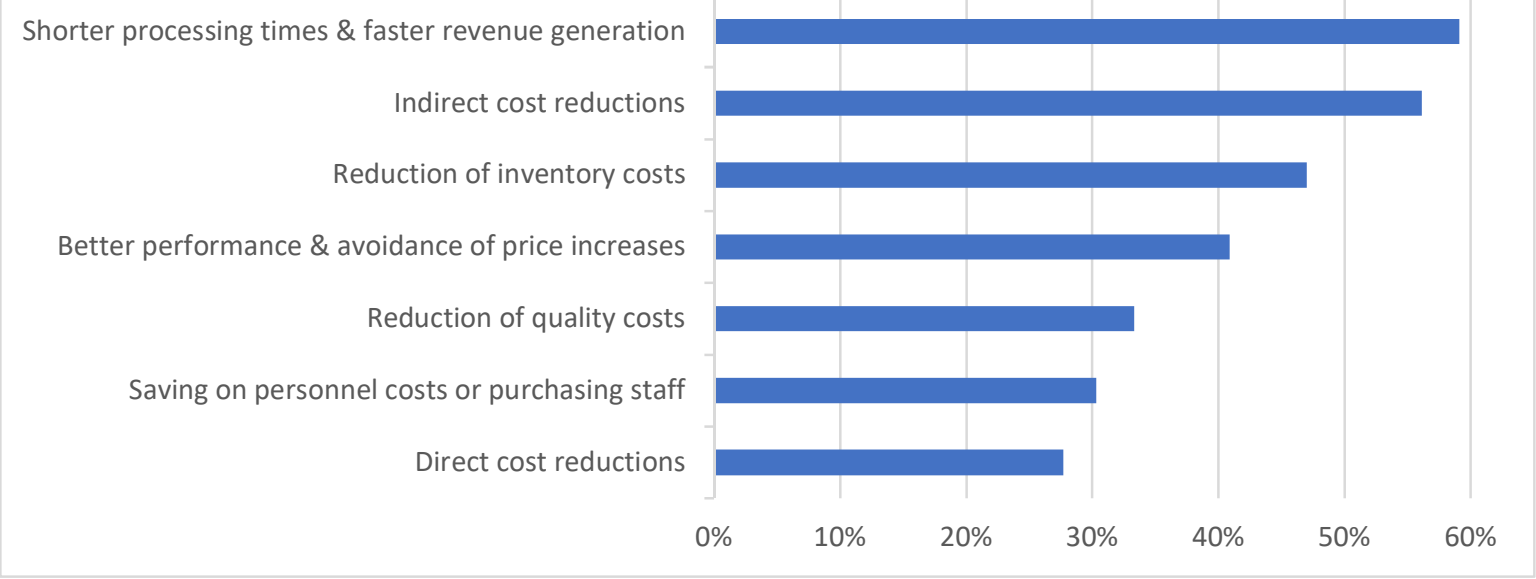

Fig. 08: Creation of Value Contributions from Industry 4.0

\section{Conclusion}

The high share of Value Added in the manufacturing industry, which is provided externally by suppliers, underpins the importance of Supply Chain Management. In doing so, purchasing must find the best suppliers for the company. Cooperation with suppliers is mainly focused on purchasing and technology. Based on this impression, it can be derived that the focus of the business relationship with suppliers is primarily on cost and product optimization issues. Communication is still very traditional. This means, the usual communication channels and personal conversations continue to be very important. In addition, it is also expected that future collaboration with suppliers will tend to become even more intensive and closer, so that it can be assumed that relationship management is preferred in comparison to anonymity.

The topic of cost reduction obviously remains the most important challenge for purchasing. Here, the largest contributions to Company Value growth continue to be seen and demanded by management. The basis for this, however, is an excellent supply and quality performance of the suppliers, which has to be ensured by purchasing. For this purpose, a close exchange is necessary, which builds on the previous developments of Industry 4.0. The suppliers must be reliable partners who have sufficient qualifications so that they can make the expected contribution to cost and product optimization. It is already an important differentiating factor whether complex products are handled with a supplier or whether suppliers are only used for simple services due to the cost structure. Likewise, the communication with suppliers will increasingly focus on it. Classification thus continues to progress.

The benefit or Value Added of working with suppliers exceeds the additional expense, the opposing effects, significantly. It is therefore still very interesting for companies in the manufacturing sector to entrust suppliers with tasks that do not affect the own core competencies in order to avoid higher structural costs on the one hand and to generate additional value on the other. Furthermore, it can already be seen that a development boost for Supply Chain Management comes from Industry 4.0. The increasing networking with suppliers means that process and information flow improvements do not only contribute to cost efficiency, but also reduce transaction times and generate sales faster. Thus, purchasing contributes sustainably to employment protection in one's own company and at the same time is the engine for company growth in terms of gaining further market share. 


\section{List of references}

Appelfeller, W., \& Buchholz, W. (2011). Supplier Relationship Management - Strategie, Organisation und IT des modernen Beschaffungsmanagements [Supplier Relationship Management - Strategy, Organization and IT of modern Procurement Management]. Wiesbaden: Gabler Verlag | Springer Fachmedien Wiesbaden GmbH.

Arndt, H. (2018). Supply Chain Management - Optimierung logistischer Prozesse [Supply Chain Management Optimization of logistics Processes]. Wiesbaden: Gabler Verlag | Springer Fachmedien Wiesbaden GmbH.

Arnold, U. (1997). Beschaffungsmanagement [Procurement Management]. Stuttgart: Schäffer-Poeschel.

Arnold, U. (2000). Beschaffung am Scheideweg: Orientierungen auf dem Weg zum modernen Supply Chain Management [Procurement at a crossroads: Orientations on the way to modern Supply Chain Management]. In: Beschaffung aktuell, Ausgabe 8/2000, S. 42-44.

Autry, C.W., \& Moon, M.A. (2016). Achieving Supply Chain Integration - Connecting the Supply Chain Inside and Out for Competitive Advantage. Old Tappan, New Jersey: Pearson Education, Inc.

Baumgarten, H. (2004). Entwicklungsphasen des Supply Chain Managements [Development phases of Supply Chain Management]. In: Supply Chain Steuerung und Services, S. 51-60. Berlin, Heidelberg: Springer-Verlag.

Fandel, G., Giese, A., \& Raubenheimer, H. (2009). Supply Chain Management: Strategien - Planungsansätze Controlling [Supply Chain Management: Strategies - Planning Approaches - Controlling]. Berlin, Heidelberg: Springer-Verlag.

Federal Statistical Office. (2018). Produzierendes Gewerbe - Kostenstruktur der Unternehmen des Verarbeitenden Gewerbes sowie des Bergbaus und der Gewinnung von Steinen und Erden 2016 [Manufacturing industry Cost structure of manufacturing companies, as well as mining and quarrying of stones and dirt in 2016]. Fachserie 4, Reihe 4.3 vom 04.06.2018.

Freiwald, S. (2005). Supply Chain Design [Supply Chain Design]. Frankfurt am Main: Peter Lang GmbH, Europäischer Verlag der Wissenschaften.

Hofbauer, G., Glazunova, A., \& Hecht, D. (2015). Strategische Lieferantenauswahl [Strategic Supplier Selection]. Working Paper, Heft Nr. 36. Ingolstadt: Technische Hochschule Ingolstadt.

Mau, M. (2003). Supply Chain Management - Prozessoptimierung entlang der Wertschöpfungskette [Supply Chain Management - Process optimization along the Value Chain]. Weinheim: WILEY-VCH Verlag GmbH \& Co. KGaA.

Monczka, R.M., Handfield, R.B., Giunipero, L.C., \& Patterson J.L. (2015). Purchasing \& Supply Chain Management. Boston: Cengage Learning Emea.

Official Journal of the European Communities. (2007). VERORDNUNG (EG) Nr. 586/2001 DER KOMMISSION vom 26. März 2001 zur Durchführung der Verordnung (EG) Nr. 1165/98 des Rates über Konjunkturstatistiken: Definition der industriellen Hauptgruppen (MIGS); geändert durch Verordnung (EG) Nr. 656/2007 der Kommission vom 14. Juni 2007 [COMMISSION REGULATION (EC) No 586/2001 of 26 March 2001 implementing Council Regulation (EC) No 1165/98 concerning short-term statistics: definition of major industrial groups (MIGS); amended by Commission Regulation (EC) No 656/2007 of 14 June 2007].

Official Journal of the European Union. (2003). EMPFEHLUNG DER KOMMISSION vom 6. Mai 2003 betreffend die Definition der Kleinstunternehmen sowie der kleinen und mittleren Unternehmen (2003/361/EG) [RECOMMENDATION OF THE COMMISSION of 6 May 2003 concerning the definition of micro, small and medium-sized enterprises (2003/361/EC)].

Oliver, R.K., \& Webber, M.D. (1982). Supply-Chain Management: Logistics Catches Up with Strategy. Outlook 5, No. 1, pp. 42-47.

Schäffer, U., \& Weber, J. (2005). Bereichscontrolling - Funktionsspezifische Anwendungsfelder, Methoden und Instrumente [Division Controlling - Function specific Applications, Methods and Tools]. Stuttgart: SchäfferPoeschel Verlag.

Schulte, C. (2004). Logistik: Wege zur Optimierung der Supply Chain [Logistics: Ways to optimize the Supply Chain]. München: Verlag Vahlen. 